\title{
Settlement Analysis of Piled Raft Foundation System (PRFS) in Soft Clay
}

\author{
SrinivasaReddy Ayuluri ${ }^{1}$, B. Vamsi Krishna ${ }^{2}$ \\ ${ }^{I}$ (PG Scholar, Civil Engineering Department, MallaReddy Engineering College, Hyderabad, \\ Telangana, India) \\ ${ }_{2}^{2}$ (Assistant Professor, Civil Engineering Department, MallaReddy Engineering College, Hyderabad, \\ Telangana, India)
}

\begin{abstract}
The piled raft foundation allows the high load bearing capacity and reduces the settlements in soils at very economic way as compared with the conventional foundation designs. This paper presents combinations of 3-D numerical analysis (by Plaxis 3D Foundation v 1.1) of piled raft foundation on clayey soil to investigate the behaviour of piled raft system in soils under different loading conditions. The settlement was measured at the centre of the models of pile raft with (single, two, three \& four) piles. Finally, the behaviour of piled raft foundation w.r.t effect of number of piles, spacing between piles, elastic of modulus and raft size on the load carrying capacity of piled raft foundation system (PRFS) are assessed and conclusions are made.
\end{abstract}

Keywords: Plaxis 3D Foundation, Pile raft foundation System (PRFS), Settlements, Soil.

\section{Introduction}

To carry the excessive loads that come from the superstructures like high-rise buildings, bridges, power plants or other civil structures and to prevent excessive settlements, piled foundations have been developed and widely used in recent decades. However, it is observed that the design of foundations considering only pile or raft is not a feasible solution because of the load sharing mechanism of the pile-raft-soil. Therefore, the combination of two separate systems, namely "Piled Raft Foundation systems" has been developed (Clancy and Randolph (1993)) [1].

Piled raft foundation system is verified to be an economical foundation type comparing the conventional piled foundations, where, only piles are used for the reducing both total and differential settlements and the contribution of the raft is generally disregarded.

In this study, behavior of the piled raft foundation systems under axial loads has been investigated by comparing the traditional design approaches and the current design approaches by parametric analyses. In the literature, there are plenty of researches focusing of these parameters, like; the number of piles, length of piles, diameter of piles, pile spacing ratio, location of piles, stiffness of piles, distribution of load, level of load, raft thickness, raft dimensions and type of soil. However, through these parameters, the number of piles, length of piles and level of load are emphasized in this study. Effects of these parameters are discussed with the solutions of finite element models. To this end, parametric analyses are conducted via the software Plaxis 3D and compared with the experimental results done by (Mr. Mudhafar Kareem Hameedi) - Thesis, experimental and theoretical for piled raft foundation system in soft clay (2011) [2].

\subsection{Aim of the Thesis:}

This study aims to describe and clarify the load sharing mechanism between the un-piled \& of piled raft foundation systems (PRFS) by considering the ratio of raft /pile load sharing under variable conditions (load levels, pile lengths, spacing and number of piles). The finite element method through Plaxis 3D Foundation software is adopted to evaluate the effect of parameter on the load-settlement behaviour of the PRFS and compared with the available experimental results. This parameter is the scale factor effect on the load-settlement behaviour of PRFS.

\subsection{Introduction}

\section{Literature Review}

In the design of foundations, shallow foundation is the first option where the top soil has sufficient bearing strength to carry the superstructure load without any significant total and differential settlements to prevent damage of infrastructure and superstructure. However, in the last decades the need for high-rise buildings and high-loaded superstructures has been increased rapidly, even in the lands with poor subsoil conditions. Therefore, the need for foundations with high bearing capacity and showing low settlement values, both total and differential, has also been increased. These types of foundations can be constructed as a shallow 
foundation after the application of ground improvement techniques or as a piled foundation which transfers the excessive load to a deeper and stiffer stratum through the piles and reduces the settlements.

This chapter presents a brief review of previous researches on piles, rafts, pile groups and piled raft foundations. However, the main attention is on design methods and analyses of piled raft foundations. Chapter may be outlined as;
a. Single Piles
b. Pile Groups
c. Raft Foundations
d. Piled Raft Foundations
e. Finite Element Programs: Plaxis 3D

\subsection{Piled Raft Foundations}

Piled raft foundations are the composite structures which consist of three elements; piles, raft and the subsoil. Applied loads are transferred to the subsoil both through the raft and the piles. This load transfer mechanism can be simply shown in Fig. 1. Load sharing between raft and piles is the main distinctive feature that diversifies this type of foundation from other type of piled foundations' design.

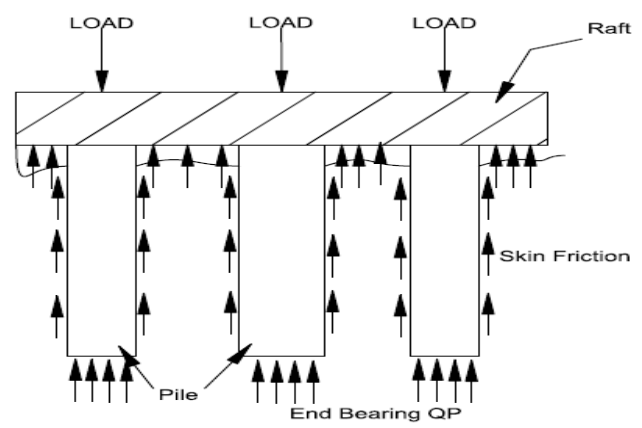

Fig.1. Simplified load transfer mechanism of piled raft foundation.

Randolph (1994) has presented three design approaches for the piled raft foundations in his state-of-the-art report as:

1. The Conventional Approach: Piles are designed to carry the majority of the load.

2. Differential Settlement Control: Piles are located in order to reduce the differential settlement, rather than the overall average settlement.

3. Creep Piling: Piles are designed to operate at a working load (70-80\% of the ultimate capacity) at which significant creep occurs.

In conventional design approach, loads are assumed to be carried only by the piles or by the raft. However, in the design of piled raft foundations, the load sharing between piles and the raft is taken into account. Naturally, this load sharing improves the underestimated load capacity of the foundation comparing with the conventional approach, considering the properties of the piles and the raft remain unchanged. In addition, the piles may be used to control the settlement rather than carry the entire load in the piled rafts. Tan and Chow (2004) [3] illustrated the usage benefit of piles and raft together in the design of foundations in Fig. 2.

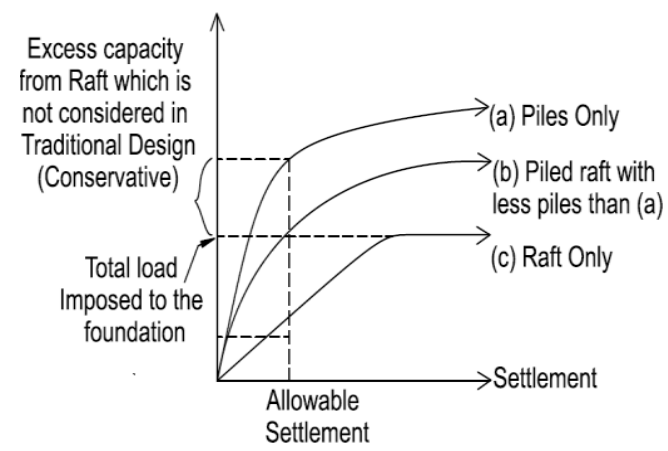

Fig.2. Concept of piled raft (Tan and Chow, 2004) [3]

\section{Methodology}




\subsection{Finite Element Program: Plaxis 3D}

Plaxis is a company based in the Netherlands, developing software under the same brand name; Plaxis. The Plaxis 3D program is a three-dimensional finite element program used to make deformation and stability analysis for various types of geotechnical applications (Reference Manual, Plaxis). The user interface of the Plaxis 3D consists of two sub-programs as Input and Output. Properties of soil and other elements (boreholes, embedded piles, plates etc.) are assigned to the elements by using material data sets by the Input interface. The basic soil elements of the 3D finite element mesh are the 10-node tetrahedral elements (Fig. 3).

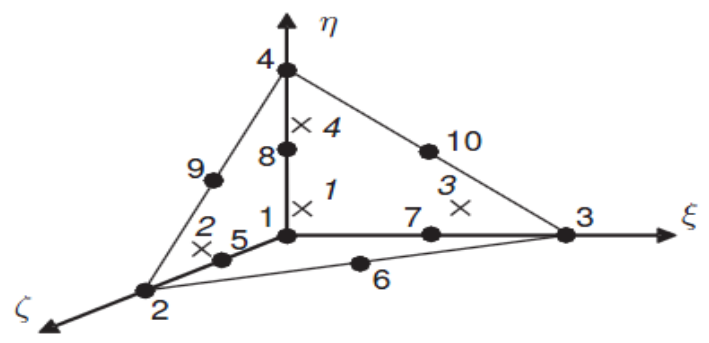

Fig.3. 3D soil elements (10-node tetrahedrons) zone (Reference Manual, Plaxis)

\subsection{Modeling of Pile Raft}

The model of pile raft foundation with different configurations has been done by considering the raft (steel plate) and the pile is of concrete and with constant diameter and length.

Table I: Properties of Pile \& Raft

\begin{tabular}{|c|c|c|c|c|}
\hline S. No & Material & Properties & Value & Raft Thickness (cm) \\
\hline \multirow{2}{*}{1} & \multirow{2}{*}{ Raft (Steel Plate) } & Elastic Modulus, $\mathrm{E}^{*}\left(\mathrm{kN} / \mathrm{m}^{2}\right)$ & $2 \times 10^{8}$ & 1.2 \\
\hline & & Poisson's Ratio, $v$ * & 0.33 & 0.6 \\
\hline \multirow[t]{2}{*}{2} & \multirow{2}{*}{ Pile (Concrete Pile) } & Elastic Modulus, $\mathrm{E}^{* *}\left(\mathrm{kN} / \mathrm{m}^{2}\right)$ & $2.9 \times 10^{5}$ & \\
\hline & & Poisson's Ratio, $v^{*}$ & 0.15 & \\
\hline
\end{tabular}

The properties values of the pile and raft (Table 1), given by *Bowles (1997) [4] and **Mudhafar Kareem (2011) [2], are used.

Table II: Material properties and pile model used for the numerical model.

\begin{tabular}{|c|c|c|c|c|c|c|}
\hline \multirow[t]{2}{*}{$\begin{array}{l}\text { Material } \\
\text { Properties }\end{array}$} & Type of Layer & $\begin{array}{lr}\text { Unsaturated } & \& \\
\text { saturated } & \text { Unit } \\
\left(\mathrm{kN} / \mathrm{m}^{3}\right) & \end{array}$ & $\begin{array}{l}\text { Elastic } \\
\text { Modulus, E } \\
\left(\mathrm{kN} / \mathrm{m}^{2}\right)\end{array}$ & $\begin{array}{l}\text { Poisson's } \\
\text { Ratio, v }\end{array}$ & $\begin{array}{l}\text { Undrained } \\
\text { cohesion, } \mathrm{C}_{\mathrm{u}}\end{array}$ & $\begin{array}{ll}\text { Angle } & \text { of } \\
\text { Shearing } & \\
\text { Resistance, } & \varnothing \\
\left({ }^{0}\right) & \end{array}$ \\
\hline & Soft Clay & 18.6 & 15000 & 0.35 & 25 & 0 \\
\hline \multirow{3}{*}{ Pile Model } & $\begin{array}{l}\text { Pile Diameter, } \\
D_{p}(\mathrm{~cm})\end{array}$ & $\begin{array}{l}\text { Pile length, L } \\
(\mathrm{cm})\end{array}$ & $\begin{array}{l}\text { Raft size, } L_{r} x \\
B_{r}(\mathrm{~cm})\end{array}$ & $\mathrm{L} / \mathrm{D}_{\mathrm{p}}$ & $\mathrm{L} / \mathrm{B}_{\mathrm{r}}$ & Spacing $(\mathrm{cm})$ \\
\hline & 1.0 & 40 & $6 \times 6$ & 16 & 6.67 & \multirow{2}{*}{$7.5 \mathrm{~cm}$} \\
\hline & 2.5 & 40 & $15 \times 15$ & 16 & 2.67 & \\
\hline
\end{tabular}

The embedment length ration $\mathrm{L} / \mathrm{D}_{\mathrm{p}}=16$, the spacing between piles are kept constant about 3 times the diameter of pile for large and small scale models. Table (1) shows the material parameters of the raft and pile.

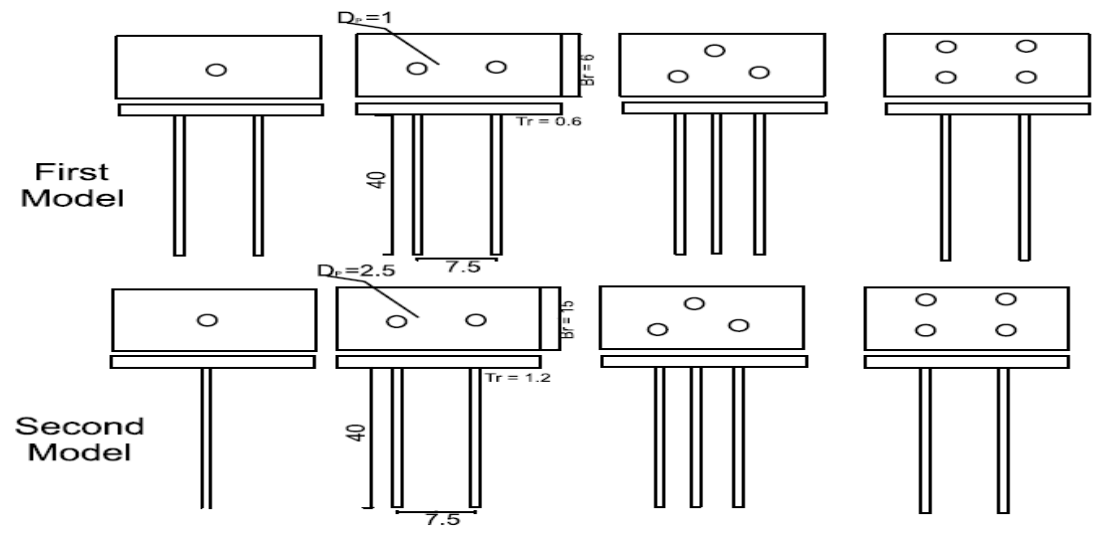

Fig. 4 Models of Piled raft for Numerical Analysis 
The computer oriented finite element method has become one of the most powerful tools in the analyses of engineering problems. In the present work, the PLAXIS Structural Static Analysis has been adopted for numerical modeling of the structural response.

PLAXIS 3D Foundation is finite element analysis software. The flexibility, capabilities, and options have been developed over many years, at the request of a worldwide user community, such that the PLAXIS program can be applied to a wide variety of engineering applications.

There are two types of structural analyses in the PLAXIS family of products, which are explained below (Vermeer and Brinkgreve, 2004) [5]: 1. Static Analysis: It is used to determine displacements, stresses effect under static loading conditions. Linear and non-linear static analyses. Nonlinearities can include plasticity, stress stiffening, large deflection, large strain, hyper elasticity, contact surface and creep. 2. Modal Analysis: It is used to calculate the natural frequencies and mode shapes of structure. Different mode extraction methods are available. Finite Element Mesh When the full geometry model has been defined and all geometry components have their initial properties, the finite element mesh can be generated. From the geometry model, a 2D mesh is generated first. The basic soil elements used for 2D and 3D finite element mesh are the 15-node wedge elements. These elements are generated from the 6-node triangular elements. The accuracy of the 15node wedge element and the compatible structural elements are comparable with the 6-node triangular element and compatibles in a 2D PLAXIS analysis. Higher order element types, for example comparable with the 15node triangle in a 2D analysis, are not considered for a 3D foundation analysis because this will lead to large memory consumption and unacceptable calculation times (Vermeer and Brinkgreve, 2004) [5].

After reviewing the results of the analysis (Fig. 6), it can be concluded that the results obtained from the experimental study and theoretical study are close indicating that PLAXIS results are accurate and can be adopted practically. Besides, the program is specified for geotechnical Engineering. The models which are performed by the finite element program with different configuration of piles are shown in Fig. 4. Six models are analyzed by the finite element program, these are:

a. Raft with single pile.

b. Raft with two piles $(2 \times 1)$.

c. Raft with three piles (triangular shape).

d. Raft with four piles $(2 \times 2)$.

The soil is modeled as elastic-perfectly plastic solid. One layer of soft clay is used. The material properties and pile model for the numerical model are shown in Table - II. Material Model The solution theory is based on the material. Material model is described by a set of mathematical equations that give a relationship between stress and strain. Material models are often expressed in a form in which infinitesimal increments of stress (or 'stress rates') are related to infinitesimal increments of strain (or 'strain rates'). All material models implemented in PLAXIS are based on a relationship between the effective stress rates $\sigma^{\prime}$, and the strain rates $\varepsilon$. The program can account for three types of material model (Vermeer and Brinkgreve, 2004) [5]: 1. The MohrCoulomb model (Elastic-perfectly plastic). 2. The hardening-soil model (Isotropic hardening). 3. Linear and non-linear behavior models for structural elements. The Mohr-Coulomb Model Plasticity is associated with the development of irreversible strains. In order to evaluate whether or not plasticity occurs in a calculation, a yield function, $\mathrm{f}$, is introduced as a function of stress and strain. A yield function can often be presented as a surface in principal stress space. A perfectly plastic model is a constitutive model with a fixed yield surface, i.e. a yield surface that is fully defined by model parameters and not affected by (plastic) straining. For stress states represented by points within the yield surface, the behavior is purely elastic and all strains are reversible (Vermeer and Brinkgreve, 2004) [5].

This classical form of the theory is referred to as associated plasticity. For Mohr-Coulomb yield functions, the theory of the associated plasticity overestimates dilatancy. The Mohr-Coulomb model requires a total of five parameters, which are generally familiar to most geotechnical engineers and which can be obtained from basic tests on soil samples. These parameters are: Young's modulus, E $\left(15000 \mathrm{kN} / \mathrm{m}^{2}\right)$; Poisson's ratio, $v$ (0.35); friction angle, $\left(0^{\circ}\right)$; cohesion, $\mathrm{C}\left(25 \mathrm{kN} / \mathrm{m}^{2}\right)$; and dilatancy angle, $\psi\left(0^{\circ}\right)$. 


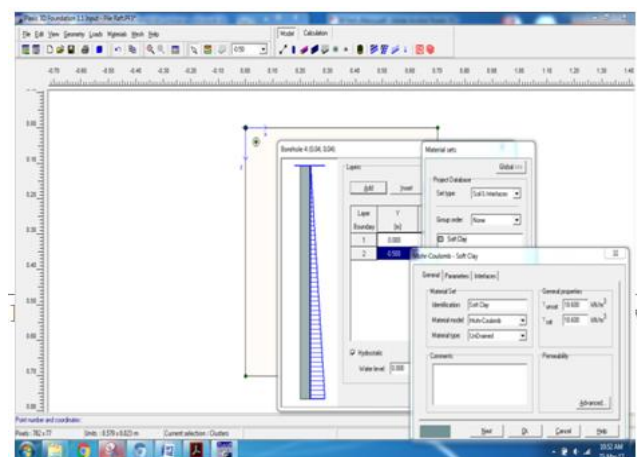

Fig. 5 Bore log data Modelled

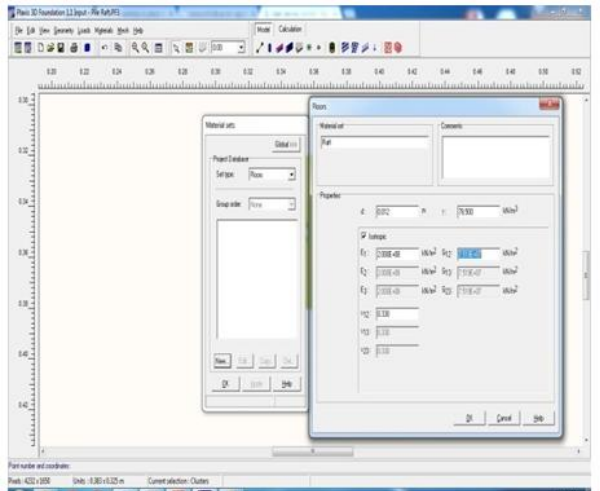

Fig. 7 Raft properties

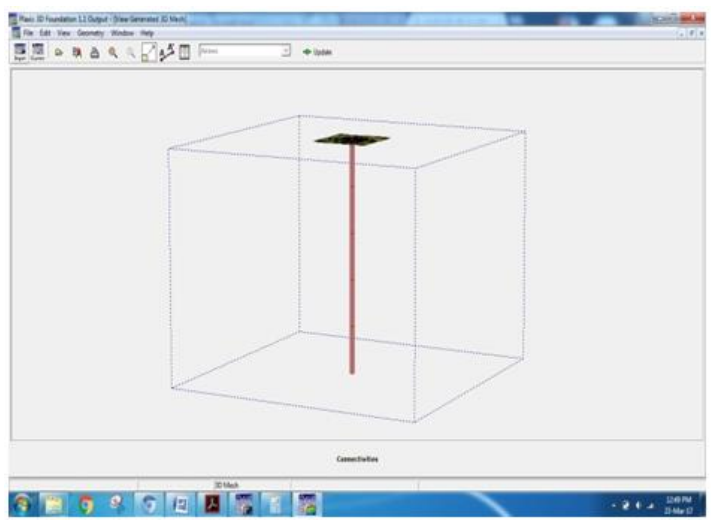

Fig.9 Single piled Raft Model

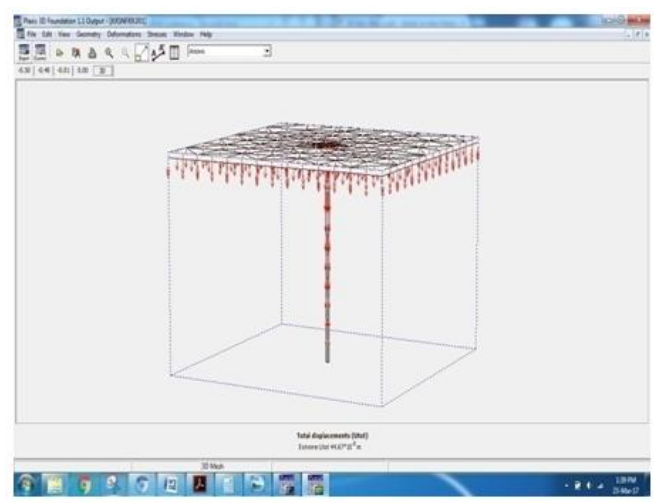

Fig.11 Total Displacement $\left(\mathrm{U}_{\text {tot }}\right)$

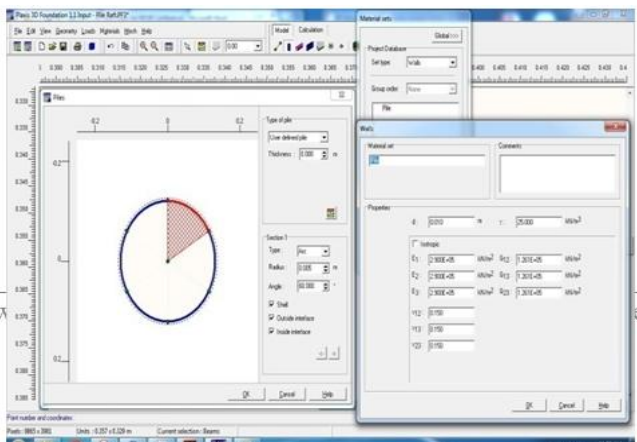

Fig. 6 Massive circular pile properties

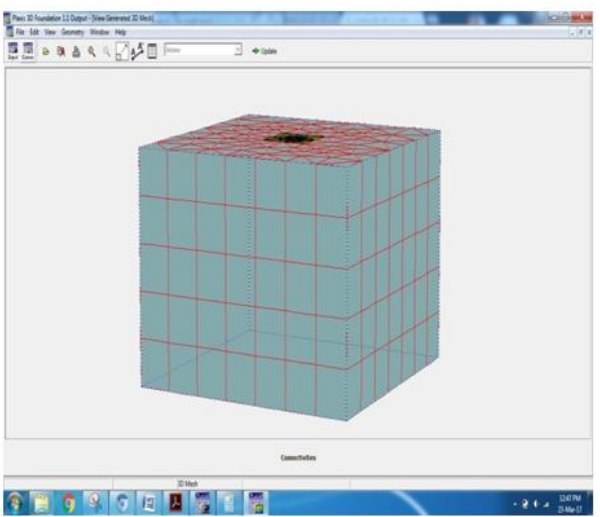

Fig. 8 Generated 3D Mesh

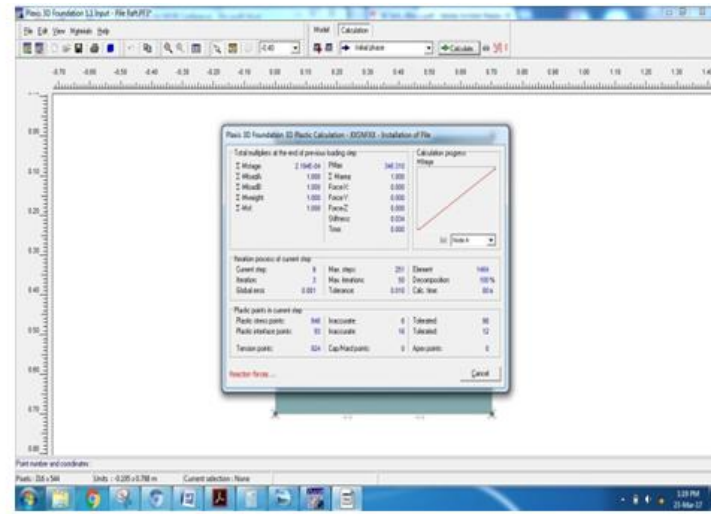

Fig.10 Calculation Phases

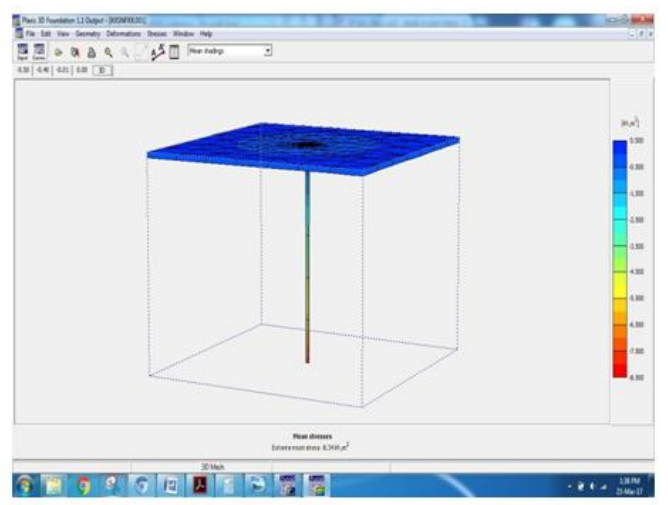

Fig.12 Mean stress for single piled raft foundation 


\section{RESULTS AND DISCUSSION}

One of the most challenging problems in soil-structure interaction is the piled raft. Piled-raft foundations have proved to be a viable alternative to conventional pile foundations or mat foundations. The load carrying capacity for the numerical model of one layer of soft clay, the settlement is plotted with the vertical applied load. Fig. 13 to 16 shows the load-settlement behavior of piled rafts of the same size of $(15 \mathrm{~cm} \times 15 \mathrm{c}$ $\mathrm{m})$ and thickness $1.2 \mathrm{~cm}$ as well as the load carried on piled raft with 1,2,3 and 4. The aforementioned Fig. 13 to 16 shows that the shape of load settlement indicates the local shear failures which are controlled. In addition, it is found that the tangent proposal can be adopted in specifying the ultimate piled raft capacity.

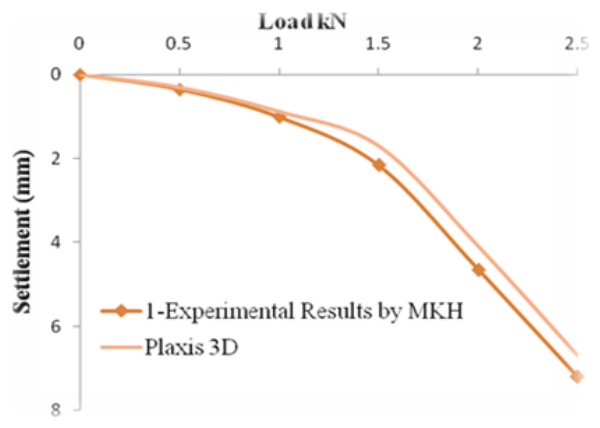

Fig.13. Load-Settlement Curve for Single Piled raft.

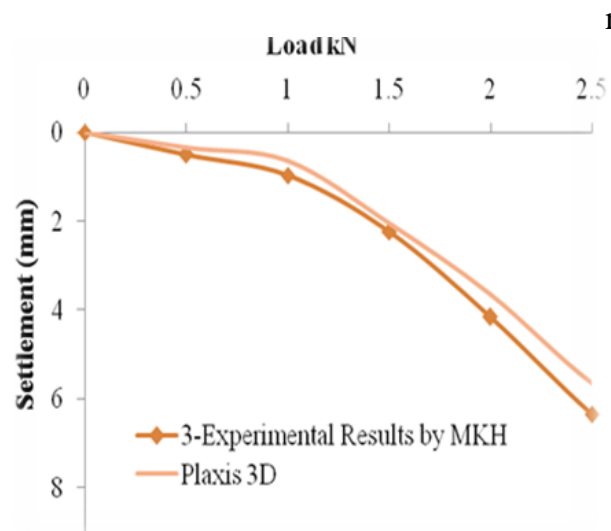

Fig.15. Load-Settlement Curve for three Piled raft.

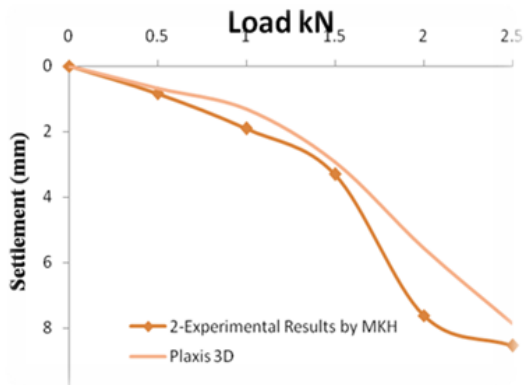

Fig.14. Load-Settlement Curve for two Piled raft.

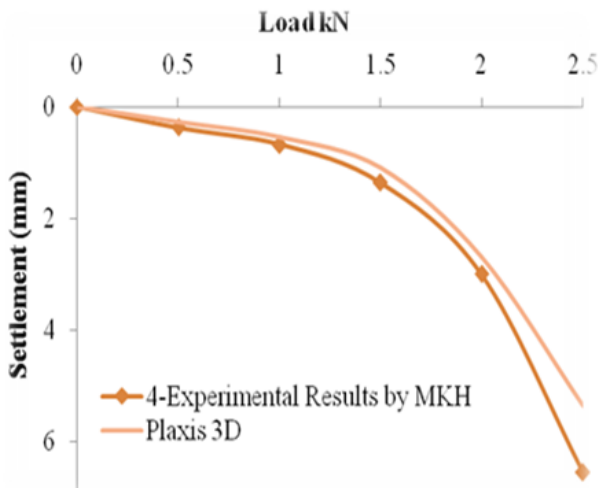

Fig.16. Load-Settlement Curve for four Piled raft.

Fig. 17 to 20 shows the load - settlement behaviour of piled rafts of the second model. The raft size is $(6 \mathrm{~cm} \times 6 \mathrm{~cm})$ and thickness of $0.6 \mathrm{~cm}$ as well as the load is carried on these configurations of the model. The pile diameter is $(1 \mathrm{~cm})$ and length $16 \mathrm{~cm}$ with ratio $\mathrm{L} / \mathrm{Dp}=16$.

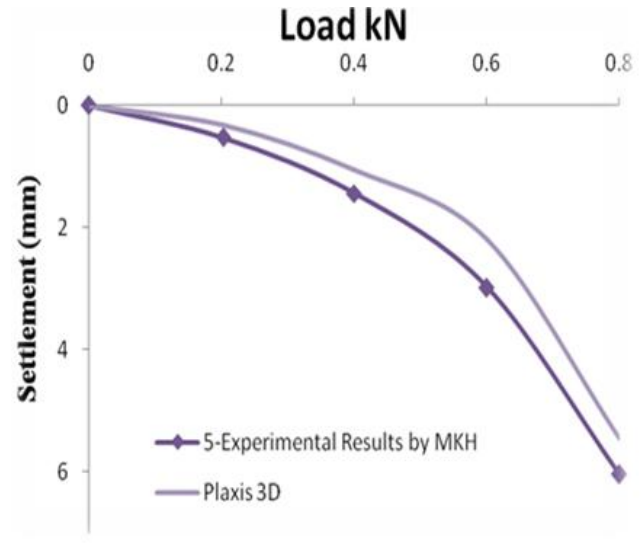

Fig.17. Load-Settlement Curve for Single Piled raft.

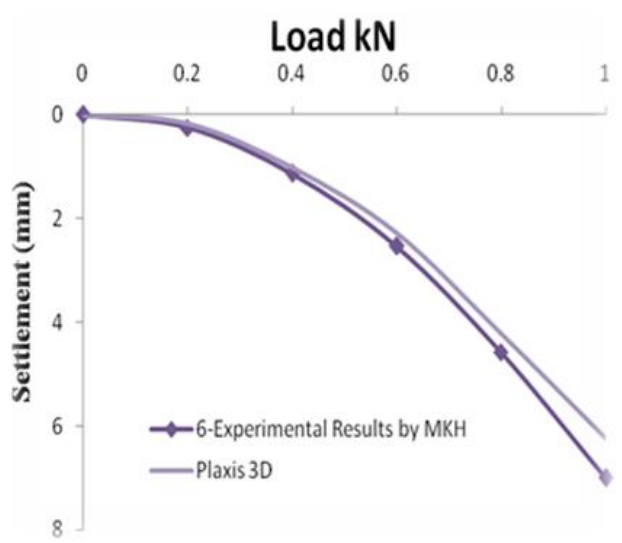

Fig.18. Load-Settlement Curve for two Piled raft. 

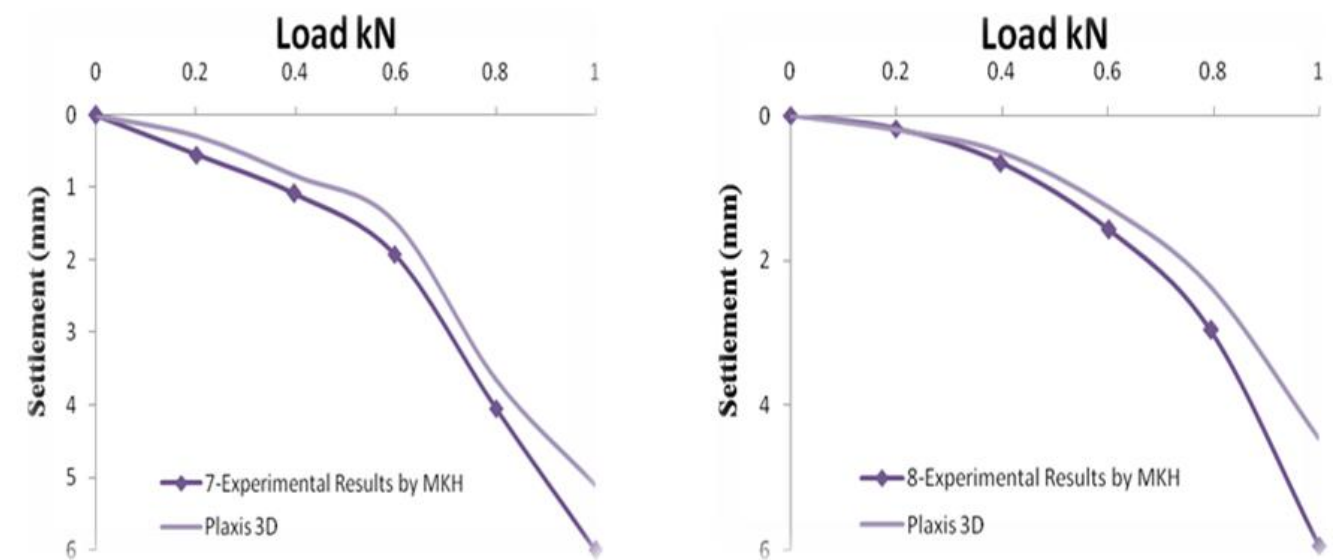

Fig.19. Load-Settlement Curve for Three Piled raft. Fig.20. Load-Settlement Curve for four Piled raft.

\section{Conclusion}

This paper summarizes the comparison between two models of the experimental work; it is found that the effect of scale factor on load carrying capacity of piled raft increases when increasing number of piles. The numerical modeling of the piled raft problem considering the load effect using the finite element method through the program PLAXIS reveals the following conclusions:

1. The load bearing capacity of piled raft increases as the number of piles beneath the raft increases.

2. The percentage of the load carried by piles to the total applied load from the numerical model for the case of four piles with raft is around $38 \%$ \& $46 \%$, while from experimental work it is $61 \% \& 65 \%$ for the $1^{\text {st }} \&$ $2^{\text {nd }}$ cases of piled raft foundation system respectively.

3. In comparison to shallow (raft) foundations, piled rafts reduce effectively the settlements.

Analysis using PLAXIS 3D compares well with the experimental values and hence it can be used for studies on piled raft foundation systems of other configurations.

\section{References}

[1]. Clancy, P. and Randolph, M. F. (1993), an approximate analysis procedure for piled raft foundations. Int. J. Numer. Anal. Meth. Geomech. 17: 849-869. doi:10.1002/nag.1610171203.

[2]. Hameedi, M. K., "Experimental and Theoretical Study for Piled Raft Foundation in Soft Clay", Unpublished M.Sc. Thesis, Building and Construction Engineering Department, University of Technology, Baghdad, Iraq, 2011.

[3]. Y.C. Tan and C.M. Chow, "Design of Piled Raft foundation on soft Ground", 2004.

[4]. Bowles, J.E., "foundation Analysis and Design", Fifth edition, McGraw-Hill", 1997.

[5]. Vermeer, P.A., and Brinkgreve, R.B.J., "PLAXIS 3D User's Manual, Version 1.1", Balkema, Rotterdam, The Netherlands, 2004. 